\title{
Effect Of E-Service Quality On Consumer Interest Buying (Case Study On The Website Korean Denim)
}

\author{
Mr. Abdlhakim Giuma Mahfud ${ }^{1}$, Vincent Soltes ${ }^{2}$ \\ I"(PHD student at the Faculty of Economics of the Technical University in Kosice, in study programme \\ Finance"). \\ ${ }^{2}$ Assoc. prof. Ing. PhD,,Technical University of Kosice, Fakulty of Economics ,Slovakia
}

\begin{abstract}
Internet users in Indonesia are increasing, creating an opportunity for business people to do business through e-commerc on the company website. Each company would have the marketing strategy to attract consumers, one of them by providing electronic services facility called or e-servi ce on the website. Through the role of e-service on e-commerce, companies can improve quality service through reliability aspect (XI), website design (X2), security / privacy (X3) and customer service (X4) to attract consumers interest buying (Y) so that the quality of online services can improve consumer buying interest through the company's website. This research was aimed to analyze the influence of e-service quality to consumers buying interest on Korean Denim's website, through purposive sampling of 150 respondents and analyzed by using multiple regression analysis on. The result showed that the e-service quality had a positive influence on co nsumers buying interest at $38 \%$ with a significance value of $0.000(<0.05)$, indicating that $\mathrm{H1}$ was accepted and generated the regression equation $Y=5,035+0.440 \times 1 X 2+0.187+0.296+1.820 \times 3 \times 4$.
\end{abstract}

Keywords: e-commerce, e-service, quality of service and buying interest.

\section{Preliminary}

Internet users in Indonesia is estimated to reach 57.8 million in 2010, with increasing use of the service via broadband technology. Today, the internet has become a medium for marketing and sales of cheap, fast and has a wide range to penetrate national borders. Along with the widespread use of the internet in the late $90 \mathrm{~s}$, the rise of online shop offering a variety of products or services through a website that is designed to be able to conduct online transactions, and lahirl ah term e-commerce (http://inet.detik.com/index.php/detik.read/ 174121/idnews /884242/idkanal/398).

Table 1. Data population of internet users in Indonesia

\begin{tabular}{|c|c|c|c|c|c|}
\hline Country & \multicolumn{5}{|c|}{ Indonesia } \\
\hline Large & \multicolumn{5}{|c|}{$1,919,445 \mathrm{~km} 2$} \\
\hline Population & \multicolumn{5}{|c|}{236200000 Life } \\
\hline Year & 2000 & 2007 & 2008 & 2009 & 2010 \\
\hline $\begin{array}{l}\text { users } \\
\text { Internet (soul) }\end{array}$ & $3,000,000$ & $130,000,000$ & $180,000,000$ & $20,000,000$ & $\begin{array}{l}28.40663 \\
\text { million }\end{array}$ \\
\hline
\end{tabular}

Source: http://www.euromonitor.com/FactFile.aspx?country=ID

According to Johnson in Kuspriatni (2009), e-commerce is an act of doing business transactions electron by using the internet as a communication medium that is most important. Meanwhile, according to Adi Nugroho (2006: 5), trade, e-commerce is defined as a way to sell and buy goods and services via the network internet, but it covers various aspects including the purchase transaction and transfer funds via a computer network. E-Commerce first introduced in 1994, electronic banner- used for promotional purposes and periklanan on a web-page (website).

According to Kasali (2011), there are some reasons offered by Visa E- Commerce Consumer (Agency for Research Monitor Visa) the increase in the number of people who shop and try on the internet. First, about $80 \%$ of respondents said online shopping time more flexible. Second, as much as $79 \%$ of respondents said they Easily compare the price so they can save even more. Thirdly, $78 \%$ of respondents to compare the products. The last $75 \%$ of respondents to look for bargains. Nugroho (2006: 19), explained that there are Several advantages trafficking in an electronic for the company, the which shorten the distance, the expansion of the market, san perlua network of business partners, and efficient. In addition to all the things that a profitable e-commerce Also has a slight disadvantage items, namely increasing individualism, lead to early disappointment, and inhumane.

Korean Denim is a company engaged in the convection jeans or denim Near Un iversitas Christian campus Maratatha 1st floor area of Student Business Unit (UBM), Prof. dr. Suria Sumantri 65 Street, Bandung. One media sales done by Korean Denim is using e-commerce on the website www.ko rendenim.com. Denim Korean website services or so-called e-service is expected to be Easily understood and run by people who access 
it, it is an effort to Anticipate market competition strategy e-commerc e were recently used by businesses via the Internet. According Supranto (2006: 227), the service or services (e-services) is a fw kine appearance, intangible and disappear quickly intervening, it can be felt rather than owned, and the customers can more participate active in the process of consuming reviews these services.

One distinctive service facility Korean website namely Chat Denim Flow (communication goes), this facility is indirect communication services between the buyer (buyer) and seller (the seller) for the purchase or means of information about the product Korean Denim. Layan's flow chat is accessible anywhere and anytime with internet facilities $\mathrm{m}$ through tablet PC, laptop, PC, mobile phone, through the application ym (yahoo messenger), g-talk (google talk), and k-talk (Korean talk). In addition there is also the facility of chat flow more services namely, Custom Design Denim (jeans design Reviews their own making). Buyers can the make the design of jeans as they wish, from the selection of underwear models, color materials, stitching, and size. Applications such is a means to implement the ideas and tastes of consumers dar i quality of service provided by Korean Denim.

According Tjiptono (2005: 121), the quality of $\mathrm{j}$ hope can be Tirrenus through the fulfillment of customer needs and desires as well as the accuracy of delivery to keep pace with customer expectations, Thus there are two the main factors that Affect the quality of expected service and services were perceived service. Excellence ch facilities at flow and design customized website Korean Denim on denim is expected to influence consumers to buy. Buying interest According to Kotler (2009: 200), is a desire that comes from within ourselves a video or from an originator in the purchasing decision, in the which the person who first proposed the idea to others for $\mathrm{m}$ embroider a product or service.

For bussiness that faces competition in e-commerce, e-commerce, each company needs to have distinctive e-service as a point of differentiation to Attract the consumers buying interest. Addressing the needs and desires of consumers through Appropriate delivery is expected to encourage consumers to buy and generate customer life time value is longer for the company. This study compiled to analyze the influence of the quality of e-services on consumer buying interest, me through reliability factor, Web site design, security or privacy and customer service.

\section{Literature review}

Service according to Kotler (2008: 85), are each tin dakan or activities that can be offered by one party to another, yan $\mathrm{g}$ is essentially intangible and does not result in any ownership. Its products can be associated or not dik aitkan on the physical products. The services provided by the facility Denim Korean www.Koreandenim.com website by using the term RCF consisting of:

1. Responsive Responding to those who access the website Korean Denim event of difficulty transacting online or just sekedar asking for information about the product Korean Denim by using the chat service flow or chatting on the facility ym (yahoo messenger), g-talk (google talk), and k-talk (Korean talk). In addition, each transaction facilitated by the procedure of transacting through the application how to buy, which features audio-visual making it easier for consumers to shop online at websites Korean Denim assisted translation tool paypal, Credit Card Visa / Master Card, Internet Banking BCA, Mandiri, and BNI.

2. Credible Fulfill all the promises given by the company to the consumer, such as sending goods in accordance with the appropriate time.

3. Fun Any person Accessing the website Korean Denim, will feel the fun for website design facilities Korean complete customized denim Denim (jeans design reviews their own making) According to customer wishes.

The above is a service in given by Korean Denim to customers / potential customers who Transact via the website services. Each company's e-commerce would have a strategy in marketing to attract consumers, one with a facility of electronic services or so-called e-service on the website. According to Hoffman et al. (2006: $69)$, e-service is electronic services or electronic services roomates connect over the Internet and can assist in solving the problem, the task of a tau transaction. E-services can be used by individuals, companies, and other eservice can be accessed through a broader network than the traditional services.

According to Bateson (2006: 333), e-service is a business concept which was developed by ecommerce where do a service relationships with customers through a world wide web (WWW) and Also completed the sale of the products and services of Reviews These companies, While the service electronically by Jeong (2007), the online services available on the Internet, where the transaction is valid for buy and sell (ISC) is possible, as opposed to a website tradi tional, the which is only descriptive information was available , and no transak the online is possible. From some of the above statement, can condition collect that e-service is a service provided by the provider of e-commerce website (profit) and non e-commerce (non-profit) to the consumer to access the website when doing online transactions or just looking for information, and the merits of an e-service (electronic service) can be felt from the consumer experience.

According to Kotler; Keller (2009: 54), the quality of online services can be judged from: 
1. Reliability / Compliance

a) Products that come presented accurately through a website.

b) Obtain customer orders from this website.

c) The products delivered on time permitted by the company.

2. Web Site Design

a) The website provides in-depth information.

b) The site does not waste time.

c) Transactions can be done easily and quickly on the website.

d) The level of site personalization right, not too much or too little.

e) trusted website has a good selection.

3. Security / Privacy

a) Feeling that consumer privacy is protected at this site.

b) Feel securely transact with this web site.

c) the Web is quite safe for the transaction.

4. Customer Service

a) The company is willing and ready to respond to customer needs.

b) When it has a problem, the website showed a genuine interest

to complete.

From the e-service description above, the expected quality of online services can improve consumer purchase interest in Korean Denim website. According buying interest Bettman \& Evans (2007: 202), is a sense of interest experienced by consumers of a product (goods and services) that influenced by the attitude outside of the consumer and in the consumer itself. Meanwhile, According to Lamb, Hair, Mcdaniel, (2007: 34), interest in buying consumerism $\mathrm{n}$ of a product is influenced by factors several model hierarchy based consumer response, among others:

1. Attention : Attention is a degree of sensitivity to the product that is being experienced by consumers, as well as knowledge of new products, which the salesperson can provide a benefit to the consumer when using the product.

2. Interest Presentation of sales Began to Attract the attention of potential customers, the which the salesperson should be trying to lure the interest of potential buyers who can turn his desire for the product. Salespeople can use the word - a word that is easy to understand, and Also had to choose the time and the right location to make a presentation.

3. Desire After catching the attention of prospective buyers, salespeople can Captivate his interest so as to create a need for products through sales blurb where it is the salesperson can do demonstrations. Salespeople can also offer a proving by conducting a test to give knowledge to the customer.

4. Action After explaining the product and its benefits, the salesperson should try to close the sale and take orders. Experiments closure can also be done by issuing an objection buyer, so the salesperson can have the opportunity to answer any questions or objections raised by the potential consumers. Additionally salesperson can offer products, presenting product features, advantages, benefits, and value of the products offered.

\section{Model Research}

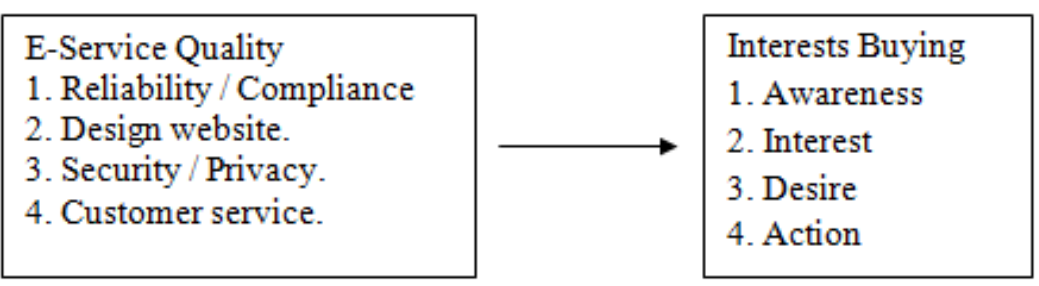

Figure 1.Model Research 2007: 34)

Source: E-Service (Philips Kotller and Kevin Lane 2009: 54), Interests Buy (Lamb, Hair, Mcdaniel,

\section{Hypothesis}

According Sugiyono (2007: 51), come into one's vision for an answer hypothesis as to the formulation of research problems. It is said, Temporarily, Because new answers given are based on relevant theory, yet is based on empirical facts Obtained through the data collection. So hypothesis can also be Expressed as a 
theoretical answer to the formula research ah mass. The hypothesis of this study is based on the formulation of the problem items, namely:

1. Ho: e-service quality has no effect on consumer interest buying.

2. H1: e-service quality has effect on consumer interest buying.

\section{Research Methods}

This type of research carried out in research in predictive research. Predictive research is research that tried to explain what will happen from a phenomenon that no (Hartono 2004). Researchers are trying to explain what will happen to relationship between e-services quality on consumers interest buying.

\section{Sampling Methods}

The sample in this study are the consumers of Denim city in Bandung that make purchases through the website Korean Denim. Sampling was done by non-probability sampling method y, using purposive sampling technique. Sampling se how non-probability sampling meant that much chance the elements to be chosen as a research subject is unknown while is a purposive sampling method is sampling that limited to Certain types of goods and be able to provide the desired information for the sample it is the only one that has or meets the criteria specified by the researchers. Number of respondents $d$ nature of this research was 150 respondents. According to Hair et al (2006), this amount meets the minimum standard sampling criteria, the which is five times greater than a number of parameters be estimated, in this study the authors use multiplication 6 to minimize the error occurred. The parameters in this elitian pen is as much as 22 questions x $6=132$ respondents, then rounded to 150 respondents.

\section{E-Service Quality \\ 1. Reliability / Compliance \\ 2. Design website. \\ 3. Security / Privacy. \\ 4. Customer service.}

\section{Interests Buying}
1. Awareness
2. Interest
3. Desire
4. Action

\section{Data Collection Technique}

Research conducted to generate the data and information required and associated with it to be written. To collect the data and information required by the authors to use it early methods of field research where the primary research tool to Obtain the data by visiting the object to be examined. Techniques used is by using a questionnaires. The questionnaire is the techniques of data collection by doing the distribution list of questions Directly to the object of study so that the data is collected author really correspond with the actual circumstances at the time of the study.

\section{Operational Variables}

In accordance with the research title is "cauldron effect of e-service bag on consumer buying interest on the website Korean Denim", then the variable operational op is as follows:

Table 2. Operational Definition of Variable $X$

\begin{tabular}{|l|l|}
\hline Variable & E-Service Quality (Variable X) \\
\hline $\begin{array}{l}\text { Variable } \\
\text { definition }\end{array}$ & \multicolumn{1}{|c|}{ E-Service is the electronic services or electronic services which are connected via } \\
the Internet and can assist in problem solving, task or transaction (Hoffman et al., 2006: 69).
\end{tabular}


Effect Of E-Service Quality On Consumer Interest Buying (Case Study On The Website Korean..

\begin{tabular}{|l|l|}
\hline & $\begin{array}{l}\text { 2. Feel secure transaction with this Web site. } \\
\text { 3. The Web is quite safe for the transaction. }\end{array}$ \\
\cline { 2 - 3 } & $\begin{array}{l}\text { Customer service } \\
\text { 1. The company is willing and ready to respond to customer needs. } \\
\text { 2. When it has a problem, the website showed a genuine interest } \\
\text { for menyelesaiaknya. }\end{array}$ \\
\hline Scale & Likert (for all indicators) \\
\hline
\end{tabular}

Table 3. Operational Definition of Variable Y

\begin{tabular}{|c|c|}
\hline Variable & Consumer Interests Buying (Variable Y) \\
\hline $\begin{array}{l}\text { Variable } \\
\text { definition }\end{array}$ & $\begin{array}{l}\text { The desire that comes from within oneself or given from an } \\
\text { originator in purchasing decisions (Kotler, 2008). }\end{array}$ \\
\hline \multirow[t]{4}{*}{ Indicators } & $\begin{array}{l}\text { Awareness } \\
\text { 1. Knowing where products Korean Denim. } \\
\text { 2. Knowing Korean Denim products. } \\
\text { 3. Know where Korean Denim product sales. }\end{array}$ \\
\hline & $\begin{array}{l}\text { interest } \\
\text { 1. An interest in using the product Korean Denim. } \\
\text { 2. The interest to buy products Korean Denim. }\end{array}$ \\
\hline & $\begin{array}{l}\text { Desire } \\
\text { 1. The desire to buy a product Korean Denim. } \\
\text { 2. The desire to look for products Korean Denim. }\end{array}$ \\
\hline & $\begin{array}{l}\text { Action } \\
\text { 1. Visit the store to buy products Korean Denim. } \\
\text { 2. Being customer Korean Denim }\end{array}$ \\
\hline Scale & Likert (for all indicators) \\
\hline
\end{tabular}

\section{Results and Discussion}

To examine the influence of e-service quality consumer interest buying in Korean website Denim used Gresi multiple re analysis. Ghozali (2009) defines the regression analysis as the study ts to measure the strength of the relationship between the dependent variable and independent variables.

Table 4. Regression Results

Model Summary

a. Predictors: (Constant), LP, K, PRI, DSW

\begin{tabular}{|l|l|l|l|l|}
\hline model & R & R Square & Adjusted R Square & Std. Error of the Estimate \\
\hline & $0.616 \mathrm{a}$ & 0380 & 0363 & 4.49782 \\
\hline
\end{tabular}

Source: Data are processed using Spss 17.0 for Windows

Table 4 shows the correlation (r) of 0616 , the which means there is a positive relationship between the two variables. A positive relationship means that if the variable $\mathrm{X}$ (quality e-service) Increase will be accompanied by the Increase of the variable Y (interest buying), while the value Outcome kore ( $r$ ) can be Obtained by the coefficient of determination ( $\mathrm{r}$ square) done to quantify the percentages of the quality of service on the interests buying is $38 \%$, while the remaining $62 \%$ are influenced by other factors not discussed in this study. Judging from the type of industry that run by Korean Denim, the authors assumed $62 \%$ of other factors are derived from the risk of online transactions such as fashion industry. Jones and Vijayasarathy (1998: 141), in 2004 revealed that people Sularto Consider online shopping more at risk dib anding shopping through print catalogs. Chang, Cheung and Lai (2005) in (Katos 2009: 30), says ba hwa risk in e-commerce are distinguished in two categories namely product risk and transaction risk. Risk Refers to ketida kpastian products or services purchased product will be as expected, sed balustrades transaction risk is the uncertainty the which would be detrimental to consumers in the transaction process.

Table 5

ANOVA $^{\mathrm{b}}$

\begin{tabular}{|l|l|l|l|l|l|}
\hline Model & Sum of Squares & df & mean Square & F & Sig. \\
\hline Regression & 1796.601 & 4 & 449150 & 22202 & $0.000 \mathrm{a}$ \\
\hline residual & 2933.399 & 145 & 20230 & & \\
\hline Total & 4730.000 & 149 & & & \\
\hline
\end{tabular}

a. Predictors: (Constant), LP, K, PRI, DSW

b. Dependent Variable: MB

Source: Data are processed using Spss 17.0 for Windows

Table 5 shows that the value of significance is $0.000(<0.05)$. This means that the model in this study right to assert a real picture of the influence of the quality of e-services to consumers to buy. 
Effect Of E-Service Quality On Consumer Interest Buying (Case Study On The Website Korean..

Table 6

Coefficients ${ }^{\text {a }}$

\begin{tabular}{|l|l|l|l|l|l|l|}
\hline \multicolumn{2}{|l|}{ Model } & \multicolumn{2}{l|}{ unstandardized Coefficients } & standardized coefficients & t & Sig. \\
\hline \multicolumn{2}{|l|}{} & B & Std. Error & beta & & \\
\hline 1 & (Constant) & .035 & .2717 & & 1853 & .066 \\
\hline & Reliability & 440 & .261 & .150 & 1685 & .094 \\
\hline & Web Site Design & 296 & .216 & .137 & 1,372 & .172 \\
\hline & Privacy & 187 & .271 & .064 & .692 & .490 \\
\hline \multicolumn{2}{|l|}{ Customer service } & .820 & .449 & .371 & 4059 & .000 \\
\hline
\end{tabular}

a. Dependent Variable: MB

Source: Data are processed using Spss 17.0 for Windows

Table 6 shows the values of regression (regression equation) is $\mathrm{Y}=0.035+0.440 \mathrm{X} 1+0.296 \mathrm{X} 2+$ $0.187+1.820 \mathrm{X} 3 \mathrm{X} 4$, where $\mathrm{a}=0,035$ has meaning when the reliability, web site design, privacy and lay anan customers do not experience Increase $=0$ (zero), the buying interest of 0,035 . While b1 $=0.440$ then has meaning when Increased reliability by 1 and other factors have Increased the Increased buying interest at 0.035 . Value $b 2=0.296$ then has meaning at the time of web site design increasing at 1 point and other factors there is no increase is in the buying interest Increased by 0.035 . Value b3 $=0.187$ then has meaning when the privacy or security Increased by 1 point and the other factors there is no increase is in the buying interest Increased by 0,187 . Value $\mathrm{b} 4=0.820$ then has meaning when the customer services increased by 1 point and the other factors there is no increase is in the buying interest increased by 0.820 . values obtained from the significant value of $0.000(<0.05)$. this means that e-service quality Affect the buying interest. By all implementation of e-service quality that has been done by Korean Denim has been rated by customers. The reliability factor, web site design, privacy, an d customer service is Believed to have a positive impact and significant influence for consumers to buy the product Korean Denim.

\section{Conclusions and Suggestions}

From the research that has been done on Kore $\mathrm{n}$ Denim, the author can draw Conclusions and try to give advice the which is expected to benefit and be Considered for the company to improve the quality of eservices on consumer buying interest Korean Denim.

From the data analysis and processing, hypothesis testing, analysis and discussion of the research, some conclusions can be drawn as follows:

1. The hypothesis of this study, namely the quality of e-service effect on consumer buying interest Korean Denim been accepted. Overall the quality of the implementation of e-services that have been performed by Korean Denim has been rated by the customers. Reliability factor, web site design, privacy, and customer service is believed to have a positive impact and influence for consumers to buy the product Korean Denim.

2. From the analysis of the coefficient of determination is known there are other factors that influence consumers to buy. Judging from the type of industry that is run by Korean Denim, the authors assumed 62\% of other factors derived from the risk of online transactions that run the Denim Korean. The author assumes that situational e-commerce industry today, providing an unfavorable impact in increasing the sales transaction so that although the customer service provided by Korean Denim has been performing well but a risk factor for the security of transactions still have a significant effect on consumer buying interest.

\section{Suggestions}

Based on the Conclusions drawn, then the next can be proposed some suggestions that may be useful for the sealed uk and Korean Denim. The suggestions proposed are as follows:

1. Give a quick response and precise. In conducting business online, of course Korean Denim required to be active and dynamic when serving the demands of consumers. In serving the demand of consumers, ensure that Korean Denim always maintain the quality of goods and timely submit the company so that it can push further towards customer repurchase Korean Denim products.

2. Offer a payment service with the cooperation of banks in Indonesia which has a network of Visa, Mastercard, etc. Inconvenience consumers against online business can arise when they me nghadapi purchase process that does not provide the security of transactions, so as to establish the credibility of eservice Korean Denim, it is necessary to support the banking as a business partner Korean Denim.

3. Completeness of the product information on the website Denim Korean needs to be improved and cared for as a medium of e-commerce transactions, the website is a medium to improve consumer product knowledge, so that the completeness of product information will greatly assist consumers in deciding the choice of products in the purchase decision process. 


\section{References}

[1]. Ali Hasan, 2009, Marketing, Yogyakarta: MedPress (Member IKAPI) Arikunto, Suharsimi. 2002. Research An Approach Procedures. Practice Revised Edition V. Jakarta: Rineka Reserved.

[2]. Asnawi, Said Kelana and Chandra Wijaya, Financial Research Methods (procedures, Idea and Control), Yogyakarta: Graha Science 2006

[3]. Anwar, S., 2007. Human Attitude; Theory and Peng size, Yogyakarta: Student Library.

[4]. Armstrong, Gary and Philip Kotler. 2002. basics of marketing. Volume 1, Interpretation Alexander Sindoro and Ben Yamin Molan. Jakarta: Prenhallindo.

[5]. Bloemer, Josee, Ko de Ruyter, Pascal Peeters, 1998,, "Investigating Bank Drivers of Loyalty: The Complex Relationship betwe en Image, Service Quality, and Satisfaction", International Journal of B ank Marketing, Vol 16, Issue 7 Date.

[6]. Buchari Alma. N Pemasara 2007. Management and Marketing Services. Bandung: Alfabeta.

[7]. Chan, Syafruddin. 2003. Relationship Mark eting: Marketing Innovations That Make Customers to its knees. PT Gramedia Pustaka Utama. Jakarta.

[8]. Chaplin, JP 2001. Complete Dictionary of Psychology. Jakarta: PT. RajaGrafindo Persada.

[9]. Chaplin, M. 2005. Gelatin. Retrieved February 14,2011, from // www. Isbuc.ac.uk

[10]. Donald R. Cooper and Pamela S. Schindler. 2003. B usiness Research Method. Eight Edition. New York: McGraw Hill.

[11]. Cronin, JJ and Taylor, SA, 1992, "MeasuringSe rvice Quality: A reexamination and Extension", Journal of Marketing, July (56): 55-68 Effect of E-Service Quality ...

[12]. Cronin, JJ and Taylor, SA, 1994, "SERVPER F Versus SERVQUAL: Reconciling Performance Based and Perception Minus E xpections Measurement of Service Quality", Journal of Marketing, January (58): 125-131.

[13]. Dharmayanti, Diah, 2006, the Impact Assessment Se rvice Performance and Satisfaction as Moderating Variable against Loy alitas Customer. Scientific Journal Univeritas Petra Su Rabaya.

[14]. Dick, AS and Basu, K., 1994, "Customer Loyalty: Toward an Integrated Conceptual Framework", Journal of Marketing T he Academy of Science, vol.22, p.99-113

[15]. Djaslim Saladin, 2003, Marketing Management, Bandung: Linda works.

[16]. Freddy, Rangkuti. 2006. Measuring Customer Satisfaction, measuring techniques and strategies to improve customer satisfaction plus an analysis of the case JP PLN. Gramedia Pustaka Utama, Jakarta

[17]. Fandy Tjiptono. 2002. Marketing strategies, Yogyakarta: ANDI Fandy Tjiptono, 2006. Marketing Services, Bayumedia, Malang.

[18]. Ghozali, Imam, 2009. Applications Multivariate Analysis with SPSS Program. Semarang: Diponegoro Publisher Agency.

[19]. Griffin, Jill, 1996, Customer Loyalty: How to Ear n It, How to Keep It, New York: Simon and Schuster, Inc.

[20]. Griffin, Jill (2002) Dwi Kartini been translated by Yahya. 2002 "Customer Loyalty How to Earn it, How to Keep it, Lexington Books. Singapore

[21]. Heizer, J. and Render, B. 2009. Management Operations. Edition 9. (Translated by: Chris Wan Sungkono). Publisher Salemba 4. Jakarta.

[22]. Hermawan Kartajaya. 2003 Marketing Strategy Plus Wins 2000 Global Competition, Gramedia Pustaka Utama, Jakarta.

[23]. Hurriyati, R. 2010. Marketing Mix n da Consumer Loyalty. Bandung: Alfabeta.

[24]. Husein Umar, 2000 Research Methodology, Application in Marketing, PT. Gramedia Pustaka Utama, Jakarta.

[25]. Husein Umar. 2001 an d Marketing Research Consumer Behavior. Jakarta: Pustaka Utama PT.Gramedia Irawan, Handi. 2009. Principles of Customer Satisfaction. Jak arta: Publisher Elek Media Komputindo

[26]. Jogiyanto, (2007), Business Research Methodology, BPFE, Yogyakarta.

[27]. Josee Bloemer, Ko de Ruyter, and Pascal Peeters, 1998, "Investigating drivers of bank loyalty: The complex relationship between image, service quali ty and satisfaction", International Journal of Ban k Marketing, vol.16 / 7, p.276 - 286, MCB University Press.

[28]. Kotler, Philip. 2005. Management Marketing, Jili d 1 and 2. Jakarta: PT. Gramedia Group Index.

[29]. Kotler, Philip. \& Keller, Kevin Lane (2009). Marketing Management 13th Edition, Volume 1, Jakarta: publisher Like, F. 2008. Marketing Management. Yogyakarta: Graha Science.

[30]. Lupiyoadi, Creep and A.Hamdani (2006). Management Services Marketing, Second Edition, Jakarta: Four Salemba.

[31]. Morissan, MA (2010). Advertising: Pe Masaran Integrated Communications. One edition, Publisher Kencana Prenada Media Group, Jakarta.

[32]. Rangkuti, Freddy, in 2003, Marketing Research, PT Gramedia Pustaka Utama, Jakarta in collaboration with the Higher School of Economics IBII

[33]. Said Kelana Asnawi and Chandra Wijaya. (200 6). Research Methodology and Financial Procedures, ideas, and, Controls. Yogyakarta: Graha Science

[34]. Saladin, D. 2006. Marketing Management. Bandung: Linda works.

[35]. Samuel H., Kosasih, AN, \& Novia, H. (2007, Ok tober). Behavior and Consumer Purchase Decision by Stim ulus Restaurants 50\% discount in Surabaya. Journal of Marketing Management 2, No. 2, 73-80.

[36]. Santoso, S. 2002. SPSS Statistics Multivariate. Jakarta: PT Elex Media Komputindo.

[37]. Sarjono Haryadi, and Winda Julianita, 2011. SP SS vs LISREL, A Introduction, Application To Reset, First Edition, Volume S atu, Publisher: Four Salemba, Jakarta

[38]. Have now, U. 2003. Research Methods for Business: A Skill Building Approach 2nd Edition, John Wiley and Son. New York.

[39]. Shaun Smith, Joe Wheeler. 2002. Managing the Customer Experience

[40]. Subagyo, Pangestu. 2000. Operations Management. First edition, Yogyakarta: BPFE.

[41]. Sugiyono. 2010. The qualitative and Quantitative Research Methods R \& D Bandung: Alfabeta.

[42]. Sugiyono. 2006. Business Research Methods. Yogyakarta: Andi.

[43]. Then Sumayang. 2003. Fundamentals of Risk Management n Production \& Operations, Publisher Salemba Four, Jakarta.

[44]. Taylor, A. Steven, Baker, L. Thomas, 1994, "An Assessment of the Quality and Customer Relationship Between Service Satisfaction in the Formation of Consumers' Purchase Intentions", Journal of Retailing, Vol.70, Number 2, pp. 163-178.

[45]. Teas, Kenneth R., 1994, "Expectations, Performance, Evaluation, and Consumers' Perceptions of Quality", Journal of Marketing, Vol. 57, October, p.18-34.

[46]. Tjiptono, Fandy, 2000, the Management Perspective da n Marketing Contemporary, Issue 1, Yogyakarta, Andi.

[47]. Tjiptono, F., 2002. Management Services, Issue II. Third printing, Publisher Andi Offset, Yogyakarta.

[48]. Zeithaml, Valarie A., Leonard L. Berry, and AN.Parasuraman, 1996, "The Behavioral Consequences of Service Quality", Journal of Marketing, Volume 60, April 1996, pp. 31-46. 